\title{
Correction to: Much ado about something: a response to "COVID-19: underpowered randomised trials, or no randomised trials?"
}

\author{
Noah A. Haber ${ }^{1 *}$, Sarah E. Wieten ${ }^{1}$, Emily R. Smith ${ }^{2}$ and David Nunan ${ }^{3}$
}

Correction to: Trials 22, 780 (2021)

https://doi.org/10.1186/s13063-021-05755-y

Following the publication of the original article [1], we were notified of the below correction in attribution of a quote, as well as a missing citation:

Original:

"For example, Brookes and Butler 2021 inaccurately claim that 'the Danish mask study showed the overall effects from mask wearing and social distancing were modest."

\section{Correction:}

"For example, Oraby et al., 2021 inaccurately claim that 'the Danish mask study showed the overall effects from mask wearing and social distancing were modest."

[citation: https://doi.org/10.1038/s41598-021-82873-2]

The original article has been corrected.

\section{Author details}

'Meta-Research Innovation Center at Stanford (METRICS), Stanford University, 1265 Welch Rd Palo Alto, Stanford, CA 94305, USA. ${ }^{2}$ Department of Global Health, Milken Institute School of Public Health, George Washington University, 950 New Hampshire Avenue, Washington, DC 20052, USA. ${ }^{3}$ Centre for Evidence Based Medicine, University of Oxford, Radcliffe Primary Care Building, Radcliffe Observatory Quarter, Woodstock Road, Oxford OX2 6GG, UK.

The original article can be found online at https://doi.org/10.1186/s13063 021-05755-y

* Correspondence: noahhaber@stanford.edu

${ }^{1}$ Meta-Research Innovation Center at Stanford (METRICS), Stanford University, 1265 Welch Rd Palo Alto, Stanford, CA 94305, USA

Full list of author information is available at the end of the article
Published online: 22 December 2021

\section{Reference}

1. Haber, et al. Much ado about something: a response to "COVID-19: underpowered randomised trials, or no randomised trials?". Trials. 2021;22: 780. https://doi.org/10.1186/s13063-021-05755-y.

() The Author(s). 2021 Open Access This article is licensed under a Creative Commons Attribution 4.0 International License, which permits use, sharing, adaptation, distribution and reproduction in any medium or format, as long as you give appropriate credit to the original author(s) and the source, provide a link to the Creative Commons licence, and indicate if changes were made. The images or other third party material in this article are included in the article's Creative Commons licence, unless indicated otherwise in a credit line to the material. If material is not included in the article's Creative Commons licence and your intended use is not permitted by statutory regulation or exceeds the permitted use, you will need to obtain permission directly from the copyright holder. To view a copy of this licence, visit http://creativecommons.org/licenses/by/4.0/ The Creative Commons Public Domain Dedication waiver (http://creativecommons.org/publicdomain/zero/1.0/) applies to the data made available in this article, unless otherwise stated in a credit line to the data. 